\title{
"WE WERE WAR SURPLUS, TOO": NICK JOAQUIN AND THE IMPOSSIBILITIES OF FILIPINO HISTORICAL BECOMING
}

\author{
Josen Masangkay Diaz \\ University of San Diego \\ josendiaz@sandiego.edu
}

\begin{abstract}
This article reads Nick Joaquin's 1983 novel Cave and Shadows alongside his persistent engagement with Filipino identity and history to argue that an investigation of Philippine historiography reveals the colonial entrapments of Filipino subjectivity. A mystery novel set in the period immediately preceding Ferdinand Marcos's 1972 declaration of martial law, it contextualizes Marcos authoritarianism within the scope of post-World War II concerns about national politics in the wake of independence. It also simultaneously grapples with overarching ideas about the legacies of colonial conquest and their effects on the Filipino common sense. Jack Henson's traversals through Manila find him grappling with the quandary of "true Filipinoness," a literary dilemma that reveals Joaquin's investment in wrestling with claims to any inherent Filipino identity as a discursive exploration of the arc of Philippine history. Rather than adhere to Filipino subjectivity as a coherent, unproblematic social formation; the novel explores it as an episteme for locating and interrogating broader systems of governance and power. Such a paradigm offers modalities for contesting Marcos's revisionist history projects. Such projects sought to recuperate Filipino identity from the dregs of a colonial past in order to celebrate its universal humanity in ways that aligned with the modernizing tactics of global development.
\end{abstract}

\section{Keywords}

Culture and History, cultural reform, historiography, national artist, The Woman Who Had Two Navels, nationalist epistemology

\section{About the Author}

Josen Masangkay Diaz is a postdoctoral fellow in the Department of Ethnic Studies at the University of San Diego. She completed her Ph.D. in Literature and Cultural Studies at the University of California, San Diego. 
"The identity of a Filipino today is of a person asking what is his identity."

- Nick Joaquin, Culture and History

Nick Joaquin wrote much of his work as permutations of that most pressing predicament above: that the identity of the Filipino is actually of a person asking what is his identity. Until his death in 2004, Joaquin was both a prolific writer with two novels canonized in Philippine literature ${ }^{1}$ and a historian; the two occupations informed by and never veering too far away from each other. In 1976, Joaquin was conferred the prestigious title of National Artist of the Philippines for his contributions to Philippine literature, ${ }^{2}$ thereby distinguishing himself during the tumultuous Martial Law years as an artist who could promote the cultural development of the nation. ${ }^{3}$ Joaquin's work is especially illuminating and generative for the precision with which it expresses a certain ambivalence around what it means to be Filipino during the post-World War II period when such a quandary was supposed to have already been solved by a post-independence nationalist resolve. In Culture and History, his formative account of Philippine historiography, Joaquin insists: "Before 1521 we could have been anything and everything not Filipino; after 1565 we can be nothing but Filipino" (14). He proceeds to argue that "the difference between [the] Spanish advent and the American [is] that the technical revolution provoked by the first produced the Filipino, while the cultural upheaval provoked by the second merely helped us to become more aware of this Filipino-ness" (14). By illustrating the Filipino in these ways, Joaquin describes a process of Filipino becoming. In the way that the inception of the Filipino names the emergence of colonial Spain in the Philippines, it also traces the materialization of a collective consciousness fashioned precisely from the necessity to delineate national, class, and racial difference in civic life. The creation of the Filipino names the ingenuity of the advent of a unified political and social body in spite of multifarious regional and linguistic divides. The comprehensibility of Filipino-ness under the U.S. colonial regime, in contrast, facilitated the realization of the Filipino through a language of self-determination crafted by an already established nationalist imaginary. Already solidified as a collective force, "Filipino" here describes the locus of potential that was birthed by the promise of an eventual, but not yet realized independence. In other words, the precision of Joaquin's episteme lies in the notion that the Filipino determines the historicity of the Philippine experience under variegated colonial regimes. More significantly, it also captures a picture of Philippine historical becoming that allowed people to imagine modes of self-articulation and living that existed beyond or in spite of the prevailing boundaries that defined what was possible under these various colonial orders.

In her exploration of Filipino identity in the novels of Philippine writers NVM Gonzalez, Amado Hernandez, Nick Joaquin, and F. Sionil Jose; cultural critic Mina Roces explains that these writers' quest for uncovering the nature of Filipino identity

Kritika Kultura 24 (2015): -092

(C) Ateneo de Manila University

<http://kritikakultura.ateneo.net> 
is, in fact, a postcolonial endeavor to assert a national identity in the aftermath of independence. Roces writes, “The quest for identity was in reality the Filipino's attempt to come to terms with his colonial past. [The Filipino] was lost because of the historical circumstances of a long colonial rule. There was a consensus that colonial rule had negative effects on Filipino identity formation" (280). Roces frames (true) Filipino identity here as existing before Spanish and U.S. colonial rule. Such an argument conceives of identity as a telos under modernity, as unproblematically lost and needing to be recovered. While such a study seems a necessary way to account for the particularities of colonial history in the Philippines in relation to the development of Philippine writing in English, I point to it here as an example of the limitations of such a historiography to attend to the ways that colonial, imperial, and nationalist epistemologies have predetermined the very methods through which Philippine history can be conceptualized and articulated. However, Roces's configuration of Filipino identity is striking in its deliberate irresoluteness. What if these writers are never able to come to terms with a colonial past precisely because the past is never actually the past? Put in another, perhaps less trite way: what if, in a scholarly urge to recover the loss supposedly expressed by these writers, one actually forecloses upon the idea that such irrecoverable loss is precisely that which can untangle identity as the locus of something more than only the signifier of a people trying to find themselves in spite of its colonial history? The very notion of a loss is dangerous, for identity as a marker of subjectivity should not be recuperated. Instead, the imperative of its irresolution as described by Roces above lies in its ability to generate a discursive aperture that showcases the battle between the continuing impositions of historical modernity inherited by colonial legacies, mandates made by nationalist theorems struggling to redefine a Philippine republic in the aftermath of World War II, and attempts to imagine Filipinoness beyond the rhetoric of decolonial nationalist configurations of representation within a new global order that was attempting to blur national boundaries. Roces's configuration of the Filipino-as-lost as a problem of historical circumstance explains that the making and unmaking of the Filipino is, in fact, a question of history. Here, the task is not to historically excavate the Filipino but to allow the Filipino to illuminate something about history.

Roces argues that Joaquin's formulation of Filipino identity "does not opt for a renunciation of the colonial past" (307) but advocates, instead, for its reconciliation. However, the adage above from Culture and History suggests something quite different from Roces's postulation. While Roces conceives of Joaquin's articulation of Filipino identity as a kind of compromise between a colonial past and a national future, I understand Joaquin's treatment of identity as something more of a rumination upon the complexity of Filipino self-determination within the limitations of historical modernity and, thereby, a dismantling of identity itself as a catalogue of history not its pre-historical truth or post-historical result. Where the invocation of personhood might invoke the "who" reserved for the subject of 
history, Joaquin's theorization of the Filipino makes an unconventional jump from the question of "who" is the Filipino" to "what is the Filipino." In this transition, Joaquin disinherits the Filipino from this subjectivity often understood as the origin and telos of history ${ }^{4}$ and instead, constructs it as the vessel of Philippine historical experience that not only bears the interests, tensions, and conflicts attached to legacies of colonialism, war, and independence, but also organizes the weight of historicity as it narrates modernity. In Renato Constantino's discussion of "Filipino" as a complex and contested category of belonging during Spanish colonial rule, he writes that " $\mathrm{t}]$ he term Filipino started as an elitist concept with racial connotations. 'Filipinos' was used to designate the creoles or the Spaniards born in the Philippines, in contrast to the peninsualares or those who were born in the Iberian peninsula" (5) and that:

[t]he original 'Filipino' was therefore both a colonial and anti-colonial. He was a purveyor of Catholicism and at the same time anti-clerical. He was for the progress of the Philippines because it meant the progress of his class. Yet this same class position did not allow him in the beginning to toy with ideas of independence because this might mean the elimination of his group as a participant in the ruling process. (5)

Constantino's description of the Filipino here positions it as a mode of Spanish colonial organization that marked national, class, and racial difference insofar as it served the aims of colonial governance in the archipelago even as it traced the beginnings of a fraught yet imperative national consciousness. Even Constantino's discussion of the conflict attached to the term Filipino as a marker of social belonging which he wrote as a forerunner to a biography of the statesman Claro Recto suggests that the era for untangling the Filipino from any ahistorical conceptualizations of it is far from over. In a more recent discussion of Filipino subjectivity, Neferti Tadiar explains the specificity of the Filipina during the current period of globalization. She reverses the question of "What is she?" to "She is what?" in order to highlight the ways that Filipina subjectivity is a being-for-others wherein the bodies and industrial and sexual labor of the Filipina is made to satiate an unceasing demand for capital within the neoliberal economy (326-7).

Both Constantino and Tadiar offer ways of materializing Filipino subjectivity as modes of class, racial, national, gender, and sexual difference. And, yet, they both speak to and with Joaquin here in their articulations of Filipino subjectivity as illuminating the production of difference rather than uncovering the ways that difference itself is manifested through historical time. Constantino's understanding of the Filipino as a pre-national technology of colonial organization, on the one hand, and decolonial insurgency, on the other, and Tadiar's theorization of the Filipina national as a project of the transnational economy are, together, more than a discussion of the Filipino during two different historical periods. Instead, it is a conceptualization of the continuity and intricacy of colonial governance as 
it colludes with the development, redevelopment, and devolvement of the third world nation-state in the era of imperialism and globalization. It is an examination of Philippine historical experience, as Tadiar might suggest, as it contends with colonial modernity. Joaquin's quandary "What is the Filipino" provides a generative historical framework with which to thread Constantino's and Tadiar's postulations in conversation with each other.

Postcolonial critics have waged formative attacks against history as the handmaiden of modernity. Such analyses elaborate upon the ways that modernity is realized through the telling and retelling of history and the imagining of a historical past to which to turn. This imagining unfolds through a humanist tradition of scientific reason and western logic cultivated by an enlightenment fixation with the pursuit of truth and progress. Some critics explore the ways that the propagation of such ideals throughout western Europe justified for respective nation-states their colonial and imperial conquest of lands and peoples deemed barbarous, savage, and in desperate need of the order such modern practices would afford. This conceptualization of historical time does not intend to simply narrate the progression of such ideals and events throughout history, of course. Rather, it dismantles history as the very framework through which modernity can be realized. History under/as modernity in its designation of (linear) time as the primary mode of organization conceives of humanity as its propagator. Only through humanity can history be conceived, and only through history can humanity be realized. In Dipesh Chakrabarty's articulation of the ways that history privileges the nationstate as the most desirable form of political community under modernity, he also centers the bourgeois individual at the center of such community (Provincializing Europe 41). Where the subject exists at the center of the nation-state formation, the subject then becomes central to the unfolding of history under/as modernity. Put in other words, history is over and over again made legitimate through the coherency of the subject. In his discussion of the linearity of Philippine historiography, Reynaldo Ileto discusses the ways that ilustrado conceptualizations of Philippine history began with the "Fall" or the break from the "dark age" of Spanish colonialism toward a Philippine national consciousness (101)..$^{5}$ Ileto writes that:

[t]he first native students of Philippine history - Jose Rizal, Gregorio Sanciangco, Isabelo de los Reyes, Ramon Paterno, and Trinidad Pardo de Tavera - saw their generation as the first to be guided by Reason rather than Superstition. As a way of liberating themselves from their colonial consciousness, they studied the ancient alphabets, literature, religion, and other aspects of pre-Hispanic society, and posited a time in the past when the Philippine archipelago was a flourishing civilization that, however, succumbed to the proffered benefits of alliance with the Spanish conquistadores. (101)

Implicit in Ileto's critique of linear historiography here and discussed by Constantino and others is the notion that the formation of Philippine national 
consciousness was dependent upon the emergence of the ilustrado as a bourgeois subject. What is most significant in Ileto's critique here is not that the formative seeds of the nation-state were planted by the ilustrados but that the ilustrado both imagined himself and was imagined to be part of a modern world. As Ileto reveals, the ilustrado is located, situated, and recognized as a subject of modernity where the subject becomes thus susceptible to historical consequence. I do not intend to insist that colonial violence cannot occur without such a designation. Instead, I explain that the formation of Filipino subjectivity at a critical moment when the dissolution of the Spanish empire occurred in conjunction with the rise of U.S. imperialism directs critical attention to the immense reach of modernity and its violent capability to usurp experience into history and to adamantly set the contours of historical and political recognizability.

In the 1970 s and 1980s, the strength of Marcos's dictatorial power hinged upon the constitutional and historical legitimization of his rule. In other words, Marcos capitalized upon Philippine history as the avenue through which he would justify his political takeover of the Philippine government and then direct nationbuilding projects that proposed the political, economic, and cultural uplift of the Philippines. Marcos's revisionist narratives focused on excavating a "true" Filipino from the dregs of the Philippines' long colonial history. In Tadhana: The History of the Filipino People, Marcos pointed to the pre-colonial indio as the bearer of a rich, complex political and cultural life before the conquest of Spain, and the ilustrado as a revolutionary intellectual that cultivated nationalist collectivities well before the implementation of U.S. colonial governance in the archipelago. In two notorious paintings commissioned by the First Couple, Ferdinand and Imelda Marcos are portrayed as "Malakas at Maganda," the first Filipino man and woman at the foundation of a Philippine creation mythology grounded upon heteropatriarchal reproductivity. Marcos's conceptualization of the origins of the Filipino people here nationalized an imagined past in order to identify a holistic Filipino subject that existed in distinction from its colonial histories. In establishing the historical positionality of the Filipino here, Marcos identifies the Filipino as the proper subject of history, as always already a subject of modernity. Where Spanish, U.S., and Japanese regimes stunted the political and cultural development of the indio, Marcos's articulation and cultivation of the Filipino in these narrative revisions instilled within Filipino subjectivity the promises of historical positionality and weight that are afforded by the comprehensibility of an imagined pre-colonial subject. Throughout the Marcos era, Filipino subjectivity served as the place where authoritarian power could usurp the Filipino from the abyss of its checkered past. Where colonial developmental discourse was grounded in the progression of the Filipino under western logics of subordination and/or assimilation, Marcos insisted that the Filipino as the modern human subject was already there.

Kritika Kultura 24 (2015): -092

(C) Ateneo de Manila University

<http://kritikakultura.ateneo.net> 
Joaquin might describe this temporal model as "Filipino time" that is, "a quality lingering over from the 'timelessness' of our culture, and as a dogged resistance against the advent of the foreign tyrant clock, and as a sign of the effort it cost to readjust from clockless to clocked time." He explains that the difficulty of the notion that "[Filipinos] were unchanged by the clock" is "grossly simplistic" (Culture and History 6). Joaquin refers to a nationalist conception of time that refuses the linear historicism of colonial bureaucratic governance in the colony and paternalistic commonwealth policies outlined by benevolent tutelage only for its western impositions over a pre-colonial culture that was made to suffer the imposition of a mode of time that was unnatural to it. Yet, as Joaquin seems to suggest, the simplicity of such an arrangement continues to rely upon a Benjaminian conception of empty, homogenous time that is not antithetical to colonial modernity but aligned with it. This timelessness of Filipino culture to which Joaquin refers conceives of an additive history unable to delineate the intimacies of collusions of peoples through trade, war, and work and to account for peoples, communities, cultures, and lives that are insoluble within modern time. Additionally, the timelessness of Filipino culture envisions a past to which the Filipino can no longer return. Such an idea, as Joaquin explains, forecloses the very possibility of comprehending the ways that Filipino culture in its hybridity generates its own possibilities of becoming at each historical iteration. Marcos's translation and utilization of historical time, on the one hand, and Filipino time, as Joaquin describes it, created what I describe as a regressive temporality. Pushing the timelessness of Filipino culture to its logical end, Marcos's vision of time "went back" to the past in order to re-enact its political development under the New Society. In other words, Marcos intended to go back so that he might justifiably and forcefully push forward in this re-creation of what it means to be Filipino. These postulations of the Filipino presence in historical time, the task of locating the Filipino in history by nationalist theoretical platforms, by Joaquin, by Marcos thus becomes the critical site of contestation and possibility that uncovers the political investments of groups vying for control over the proper direction of the nation. It also generates a discursive method for conceiving of ways out, so to speak, of the deterministic paradigms of self-actualization always already provided for the Filipino imagination.

Joaquin's novels, including the preeminent The Woman Who Had Two Navels (1961), according to Cristina Pantoja-Hidalgo, narrate "the search for a national identity" (333). She describes Cave and Shadows as "structured like a mystery thriller ... drawing on a rich store of myth and legend but locating the action in the thick of contemporary events and using a middle-class intellectual as protagonist" (333). It follows pseudo-detective Jack Henson through the streets of Manila in August of 1972 as he attempts to solve the mystery of the death of the young Helen "Nenita" Coogan. Coogan, the daughter of Jack's former wife, Alfreda, was found dead in a cave along the Pasig River referred to as the Barrio Bato. The cave is at the center of a heated struggle between Christian and neo-pagan activists over the rights to its

Kritika Kultura 24 (2015): -092

(C) Ateneo de Manila University

<http://kritikakultura.ateneo.net> 
use. The novel thus traces Jack's work to find Nenita's murderer as he also wrestles with national Philippine politics and his own tumultuous memories of his youth in Manila. This essay is an investigation of Filipino identity in Cave and Shadows as the avenue for Joaquin's historiographic exploration of Spanish and U.S. coloniality, the rise and development of Philippine nationalism, the political direction of the Philippine nation state in the aftermath of World War II and then into the martial law period, and the proliferation of Philippine culture throughout these political and historical trajectories. It argues that Joaquin's treatment of Filipino identity in addition to his re-imagination of time and space treats subjectivity as the basis for a historiography that challenges historicism itself as a mode of colonial governance and the impetus for nationalist paradigms of self-determination. In doing so, he articulates the ways that history, at once, usurps the Filipino consciousness within the regulatory confines of modernized definitions of selfhood yet also provides another imaginary through which this consciousness might be re-evaluated and redeployed.

Marcos utilizes a regressive temporality in order to reconstruct Philippine historiography and position the Filipino as a pre-existing subject of modern time, a project that cohered with his insistence upon including the Filipino within a universal humanity. Here, Nick Joaquin's 1983 novel Cave and Shadows, a text that uses the uniqueness of martial law and Marcos authoritarianism and its attendant nationalism, rethinks Philippine historiography away from Filipino subjectivity and any false notion of a "true Filipinoness." For Joaquin, recuperating the Filipino subject is far less important than articulating the ways that colonialism and nationalism have established the limits of Filipino subjectivity in the modern era.

\section{THE MANILA SUMMER AND NARRATIVE AND BODILY DECOMPOSITION}

Published in 1983-two years after the end of martial law and three years before Marcos's dramatic ousting by the People Power Movement-Cave and Shadows is set during the month before Marcos's declaration of martial law in 1972. Where September of 1972 heralded the nations' emergence into martial law, the month of August refers to the political and social climate of the country before the commencement of the authoritarian state. Marcos would ultimately cite the growing social unrest that culminated in violent protests against his administration popularly referred to as the First Quarter Storm as the impetus behind his decision to declare martial law over the country. The novel's initial descriptions of the intensity of the Manila heat attests to the urgency of this political and historical moment when established rules are broken, when tensions explode, and when previously separated factions come head-to-head in eruptive ways. For those of us who have had the mis/fortune of enduring the tropical heat of the Philippines' urban metropolis, Joaquin's elaborations of it may come as familiarly disconcerting. 
It is suffocating and passionate, and it generates an atmosphere of confusion and turmoil. In the beginning pages of the novel, Jack is reintroduced to Manila after a long absence in Davao, and it is less than comfortable. In the first lines of the novel, Jack finds "himself in a swoon" where he feels "his body droop and start steaming. . . the favor warm against his clothes [settle] back as dew on the skin and. . . spilled soup from groin and armpit" (1). The narrator explains that Jack "had been brought upon on an awful image of August. . . a month red with fire and red with blood, the month of amok, when tempers are cracked or crazed" (2). The effects of August here are specifically enacted onto and upon Jack's body. Jack is no longer himself but caught if only momentarily in a spell. Not only does his body literally shift form as it stoops, but it also becomes dehydrated of nourishment as it steams and spills. The heat facilitates Jack's disembodiment, the transformation of his whole body into various disfigurations. Additionally, August propels normally calm dispositions into fits of insanity.

As Jack's body falters under the intense heat, the narration continues to illustrate August with a promise of movement, disruption, and danger:

With the rains come a change of mood and a difference in hotness. If you felt broiled in March, you feel boiled in August. The seething month has nothing of the stillness, the candor, of summer. Its heat waves are in constant stir, building up to a fit. Danger looms if the air is unclear, like a smoke. This thickens and darkens until, overheated, it explodes - into a thunderstorm, a cloudburst, a typhoon. But the storm neither clears nor cools the air. It only feels muggier afterwards; and from the ground steams a miasma: the singaw ng Yupa, or earthsmell, that's mustiest after an August flash flood. The alternation between heat wave and hurricane accounts for the myth of August as a violent month, the myth now recalled by Jack Henson, on this August morning of 1972, as moving aimlessly he found himself on Rizal Avenue. (2)

The typhoon conjured here foreshadows the climactic events of the novel, namely the storm that results in the death of Andre Manzano and the subsequent suicide of his father, politician and activist leader Alex Manzano. This also narrates, however, a certain destabilization in which something once known to be true can no longer retain its "candor" in the face of the disarming heat. Insofar as the other summer months might be characterized by a particular "stillness," such a description of August proffers a break from normality and becomes a way to highlight the alarming specificity of the present moment in which Jack finds himself. The adamancy instilled by the directive pronoun "this" coupled with the morning dawn and the date "1972" on "this August morning of 1972" directs attention to the eruption posed by the First Quarter Storm and the declaration of martial law. As a genealogical reconsideration of these events, the invocation of heat becomes something of a rumination upon the historical weight and implications of the martial law era and its provocations. While Joaquin's presentation of heat unfolds along a linear 
trajectory where the intensity of the heat is only depicted through Jack's bodily discomforts and then eventually develops into the promise of a typhoon, the narration explains that the "storm neither clears nor cools the air" but that the climate "only feels muggier afterwards" (2). Rather than pursue any developmental illustration of the storm to its logical end, the confusion of the storm never actually dissipates but remains definitively unclear. As an explosion that never settles, this is a reconceptualization of historical time through a literary disinvestment in its progressive, developmental unfolding. Instead, time is suspended so that the August of 1972 can be considered not as absorbed by historical occurrence but lying in contestation to the schema of history. Here, historical time as a technology of modernity is rendered inadequate for grappling with the gravity of martial law within the larger framework of Philippine history.

In 1972, the Old Manila that consisted of a downtown that housed the Plaza Goiti, the Cine Ideal, and the Odeon Theater had already been virtually razed during the Battle of Manila where world powers staged its fight for control of the Pacific during World War II. As Jack traverses this city of the 1940s in 1972, he allows his memories of the prewar era to guide his present efforts to navigate this familiar-yet-different city. This is not the dissolution of Old Manila but, instead, its persistent irreconcilability in the face of development so that it must lie in stark existence with New Manila rather than become absorbed within the totalizing progression of history. In his exploration of the "city" in Philippine writing, E. San Juan, Jr. offers a lucid reading of Jose Rizal's El Filibusterismo (1891) to showcase the ways that Rizal's treatment of Manila exposes the "truth of social domination." He explains that "by offering infinite possibilities of chance encounters, coincidences, fortuitous and accidental happenings, Manila generates the conditions for the individual subject disappearing and merging with the interplay of collective forces, social classes, in order to trace the path of his/her personal destiny." For San Juan, Manila is precisely the place of encounter not simply between the colonizer and the colonized but, more importantly, for a collective body unified by "nostalgic utopian longings." Most compelling about San Juan's claim here is that the devolvement of the individual subject into the "interplay of collective forces [and] social classes" becomes the productive force that is used to expose the violences of the colonial order. In other words, it is the specific labor of Simoun in the Fili to "[fabricate] revelations behind the scene" that sacrifices the promises afforded to individual subjectivity under the colonial order by forcing it to disintegrate through the creation of something altogether different from the conditions of living shaped by civic life under colonial domination (198). Similarly, Jack's simultaneous familiarity and dissonance with Manila provides the narrative space within which Joaquin uncovers the palimpsestic remains of a war waged in the Philippines. The narration describes, "He thought of the salvaged khaki and fatigues that himself young had been belted into, in the later 1940s: the kids, then, we were war surplus too, like the jeepneys. Olive drab painted over with rainbows was our world of leftovers" (3).

Kritika Kultura 24 (2015): -092

(C) Ateneo de Manila University

<http://kritikakultura.ateneo.net> 
Jack, here, attempts to make sense of the modernization of the Philippines' capital city while its landmarks wane under the elusiveness of his memory. Yet, Jack's memories of his postwar childhood serve as the bulk of his consciousness while his physical self navigates the present-day geography of modern-day Manila well after its reconstruction. In this way, Jack's self is always constituted by this multifarious array of historical occurrence. Joaquin's mastery of the English language here-his seamless comparison of the children raised in war to the jeepneys that stayed after war's end-illustrate the transformation of the dregs of war, its surplus objects, into the very framework of modern humanity. Joaquin makes reference to the jeepneys that were "olive drab painted over with rainbows" as he definitively outlines the "world" of Jack's generation a generation of kids that were "belted into" the fatigues of war so that they would be made from war (3). Joaquin traces the ways that war surplus sets the contours of Filipino subjectivity so that it is made to bear the reconstitutions of power that are delineated after the war's official end.

The advent of national independence from the United States in 1946 in the aftermath of World War II facilitated for nationalists a new set of questions regarding the proper political development of the country. One nationalist strain, in particular, concerned itself with identifying its development with an Asian consciousness that adamantly rejected the continuing U.S. presence in the Philippines even after 1946. Most notably, the continuation of U.S. military bases in the country illustrated the most blatant disregard of Philippine national sovereignty, showcasing the imperialist desires intrinsic to the construction of the young Philippine republic. Joaquin articulates the perplexity of post-war Filipino subjectivity through Jack's meanderings and recollections. Here, Jack-as-Filipino protagonist reflects the ways that the Filipino as a nationalist paradigm grappled with the quandary of transition from commonwealth to nation, from territory to republic. The complications of Jack's remembering and the confusion of the urban space where he finds himself illustrates a struggle to assert a uniquely nationalist platform amidst the suffocations of a continuing imperial presence. Again, more than allowing Jack to represent a particular nationalist political strain, Joaquin traces the process of Filipino becoming as a distinct and continual interplay between these articulations of independence and the necessity to acknowledge the means through which coloniality underscores the very coherency of Filipino being. While Jack can only comprehend himself through the language of war, his memory grapples through and against this totality by forcing him to comprehend the hybridity of his constitution. This is not Jack's return to a past that is impossible to ascertain, as Joaquin might instruct. It is a conceptualization of Jack that is parallel with the multiplicity of the jeepney's configuration: a sense of being Filipino that stands in spite of and against the logics of war's totalizing devastation.

Jack's bodily disintegration under the heat and his simultaneous reconstruction of his self through it - that is, the frustrating work to recollect and remember 
himself in the face of his own irrecognizability is the vehicle through which Philippine history is posited and entangled by Joaquin as his work grapples with it as modernity's technology of subjectivity. In other words, the complexity of Filipino subjectivity is prefigured in the character of Jack. As a mystery novel in which Jack serves as its primary investigator, the entire unfolding of the mystery itself depends upon Jack's own cognition and reconstruction of the events that led to the various crimes. The mystery narrative seeks a certain recovery of truth that depends primarily upon the detective's own conceptualization of that truth. Insofar as Jack regains his own composure in the thick of the Manila heat, makes sense of his childhood relationships in the midst of present circumstances, and discovers the mystery of Nenita's death through larger questions of postcolonial identity; he transforms various fragmentations into a whole that is manifested, by the novel's end, in the realization of a more reconciled self. Chakrabarty has described the novel as a genre that serves to express the modern self ("Postcoloniality and the Artifice of History" 8). For Joaquin's novel-a type of postcolonial mystery novel, to be sure-Jack is the modern self through which history must unfold. ${ }^{6}$

\section{CHRISTIANITY AND THE BEATAS}

During a visit to the home of his old friends, Alex and Chedeng Manzano, Jack listens to the Manzano elder, the old-politician-turned-Christian-fanatic, Don Andong Manzano reminisce about his own politicization: "I began to see what a number of colonies we really were - a Chinese colony in trade, a Spanish colony in culture, a Washington colony in politics, a Hollywood colony in fashion, an English colony in language, a Roman colony in religion - and so forth. Even Bombay and Tokyo and Arabia had in some way colonized us" (66). Don Andong continues to outline the "paradoxes of politics" (66) as he first details his work as a campaigner for Manuel Quezon's independence bill, which earned him a senatorial seat under Quezon's administration during the U.S. Commonwealth period in the 1930s; describes his vocal opposition of the Japanese invading military in Davao, which caused political and physical danger for him during the Japanese occupation of World War II; elucidates upon the American praise that he garnered as a noncollaborator after the liberation of Manila; and finally explains his work to denounce US efforts to grant itself military and parity rights after Philippine independence. Don Andong asserts, "I can say that I never won-as the neo-colonial candidate; and was never defeated-as the anti-imperialist candidate, whether the issue was the Americans behind Magsaysay or the Americans in Vietnam. I know I could have been President-I was approached-but I preferred, alas, to be right" (67). Referencing Don Andong's most recent conversion to Christianity, Jack teases him and describes his politicization as his first "road to Damascus" (67). As a Saulturned-Paul, Don Andong's revelation of his political life encapsulates his formation 
as a Filipino national subject (66-7). Through parallel structure, he initially elaborates upon his realization that the Filipino is a ceaseless array of colonialisms. The composition of this narration describes the Filipino less as a victim of multiple colonizations but, rather, as constituted through an ongoing process of colonizing. Also borne from the "paradoxes of politics," however, this subject is fashioned out of emerging nationalisms both defined through and against the U.S. imperialist state and simultaneously shaped by anti-colonial and anti-imperialist dissent. Positioned and then repositioned according to the demands of collaborative and competitive state powers, the Filipino subject is the vehicle of nationalist and imperialist desire, on the one hand, and the breeding ground for a resistive consciousness on the other. In other words, the Filipino is not that which has always been but that which is always already becoming.

Don Andong's conversion to Christianity provides Jack with preliminary information about the death of Nenita Coogan and the religious debates that surround it. As the central mystery of the novel, its slow unfolding facilitates debates about the tenacity of colonialism, methods of decolonization, and the proper form of nationalism. Jack learns that Nenita joined a religious movement based upon the life and work of La Hermana Beata, a faith-healer of myth and legend of the $17^{\text {th }}$ century Philippines who spent a significant portion of her life living alone in the Lakan Bato (or the Barrio Bato where Nenita's dead body was found). The novel reveals that, according to the earliest accounts of the Hermana's life written by the Dominican friar Iago del Santo Rosario, Hermana was a devout Christian woman who only left her cave after a divine providence called upon her to feed and heal the poor and sick of Manila. Consequently, she became a significant figure for the Christian faithful of the Philippines: "That she has today been recovered for history is due to the altered regard for a past disdained as colonial and benighted but now prized for its vigorous folk culture: the ikons [sic] and shrines, the cults and fiestas, the custom and ceremony of what may no more be scorned as folk Catholicism" (107). Canonized as the "first native saint of the Philippines," Hermana and the eventual rediscovery of the Lakan Bato in 1970 embodied for the church and its followers the sanctity of Christianity in the Philippines and justified the advancement of new paradigms that revolved specifically around the pioneering presence of the Hermana (109). In the mid-1960s, a journalist explained that the Hermana and the Beatas, the circle of women who devoted themselves to prayer and active service in the name of God and with whom the Hermana worked most closely, constituted the "first Women's Lib Movement in the Philippines" (107). When the same journalist later pronounced that the Hermana was not, in fact, lauded by the church but forced out of her cave for being a pagan, s/he sparked a series of bitter battles between the church and the neo-pagan groups of the Philippines, each of whom adamantly defended their claims to the Hermana and to their rights to worship at the cave (109-110).

Kritika Kultura 24 (2015): -092

(C) Ateneo de Manila University

<http://kritikakultura.ateneo.net> 
With these narratives, Joaquin details his fascination with the emergence of the Beatas as a religious movement in the $17^{\text {th }}$ and $18^{\text {th }}$ centuries. In Culture and History, Joaquin describes the Beatas as having emerged from the Dominican and Franciscan orders of the Spanish colonial regime but also as often working in opposition to its authority. Through an interweaving of myth, hearsay, gossip, and archival research; Joaquin explains in Culture and History that the origin of the beatas is attributed to the rise of the Hermana Sebastiana de Santa Maria, a poor india who "heralded a mystical movement that was to run a hundred years and to leave an enduring legacy: the first native religious communities" (101). Hermana Sebastiana served as an intermediary for Dominican friars who had yet to establish a partnership with the laypeople under colonial rule. Working in conjunction with the religious order of the colonial government, she would, at once, remain outside the "cloister" of the clergy but remain devoted to promoting religious doctrine amongst the native people. Joaquin continues to chart the religious conversions of Antonia Ezguerra and Fracisca Fuentes, two young widows from Manila who became hermits in the name of their unwavering devotion to God. The three women established a "little beaterio" that served as a "coming together of the Philippine races. Antonia Ezguerra was a creole, Francisca Fuentes probably a mestiza, the Hermana Sebastiana an India; and they were later joined by Juana de la Trinidad, another older widow who had long been living as a recluse. Another member of this primitive community was a native woman named Lorenza, who seems to have been Antonia's maidservant but who was raised to the status of hermana" (107). As a community of beatas that worked amongst the poor and tended to the sick, these women were recognized by the religious order yet struggled to "be recognized as a formal community and to found a house where women not content with ordinary devotion could test their competence for heroic sanctity" (108). In spite of this serious opposition from Dominican authorities, they eventually saw the establishment of the "Beaterio de Santa Catalina, the first Philippine religious community" (109). Joaquin follows the progression of the community, elucidating upon the emergence of other prominent beatas and their respective conflicts with various religious officials. Joaquin's intent to trace the formation of the first Philippine religious community also outlines the politics of racialized, gendered, and classed subjectivities during the $17^{\text {th }}$ and $18^{\text {th }}$ century under the Spanish crown. While it is significant that such a community brought together indio, Spanish, Chinese, and Japanese noble and working class women under a common movement, ${ }^{7}$ it is much more momentous to consider that its struggle for official recognition from the colonial state and then inability to become fully usurped within such forms of recognizability illustrates the extent of its possibility as a mode of anti-colonial justice (121). That is, even as the "dilemma of [the] native beati was that, even if they had wanted to, they could not have been regular religious-members, say of the Dominican or the Franciscan Orderbecause the policy then was not to admit natives to the regular religious orders" (116). The beatas were:

Kritika Kultura 24 (2015): -092

(C) Ateneo de Manila University

<http://kritikakultura.ateneo.net> 
an underground movement, as may be gathered by the attacks on it by its enemies in Church and State, enemies who, with reason, distrusted it, like everything novel, as bizarre, irregular, unconventional, freakish, nonconformist, anomalous, abnormal, and illegal. . . Even its early friends... seem to have feared it, since they fought it, because they couldn't quite place it; and the more light-minded of the public were ready to believe anything of these queer creatures who were neither fish nor fowl, not of the cloister and yet not of the world. (122)

Produced out of an insistence upon "human solidarity" based upon a trope of suffering under inhumane conditions and the need to "nourish each other beyond the grave"-neither a belief in the Darwinian separation of the fittest nor a propagation of a universal humanity to which everyone equally belongsthe beatas advanced a social framework that labored to alleviate the patriarchal mandates of the Spanish religious order (118). Even though the archbishop of Manila in 1771 demanded that the beaterio remove "vows of chastity, obedience and poverty" from its mandates, all of which adamantly opposed the reproductive aims of the colonial government, they "more or less ignored both king and archbishop and continued receiving girls who, after undergoing a two-year novitiate during which they were taught to read, write and sew, were allowed to make temporary vows, for a seven-year period, at the end of which they could make a perpetual profession as members of the beaterio" (121). Joaquin's conceptualizations of the beatas as originating from an individual woman of a particular social caste and then challenging this individuality through collective acts of resistance illuminate the mode through which individualized subjectivity sanctioned colonial state power. Joaquin's illustration of the transference of history between the Hermana Sebastiana to the various beatas who came after her maps the modes through which colonial and state power and its accompanying resistances shaped and shifted throughout the $17^{\text {th }}$ and $18^{\text {th }}$ centuries. Joaquin explains that the beatas "have proved to be so adaptable to every shift of history because they were based on audacity and experiment" (122). Such adaptability, as Joaquin reveals, emerges as a refusal of the rigid subjectivity proffered by the colonial state insofar as the beatas refused their nationalities and worldly possessions, seeking community amongst themselves and functions, instead, through a collective labor enacted in devotion to God and community.

Similar to the ways that Constantino has sought to destabilize the Filipino as both a method of colonial organization around axes of race and class and a means of national coherence, Joaquin, too, treats the beatas as emblematic of a dynamic and complex Filipinoness that was fashioned from colonial policy and practice and formed through resistive decolonial and anti-colonial struggle. Joaquin insists, however, that religious movements offer an incisive medium through which such concerns around Filipinoness might be addressed and processed in useful ways. 
Toward the end of the novel, a deadly typhoon has climactically resulted in the death of the young Andre Manzano and interrupts if only momentarily the youth movement that has been brewing in Manila around rights to the Barrio Bato cave. In the section that begins immediately after the reader bears witness to the "boy [who] lay naked near the sill of the inner cave," Joaquin outlines a legendary story of the first archbishop of Manila sent by the Spanish crown to govern the godless people of the islands (Joaquin, Cave and Shadows 217). As the story goes, the archbishop first arrives in Acapulco the headquarters, so to speak, of the Spanish colonial government in the Americas to the bewildering cautionary words of three witches who warn him of his ill fate in the archipelago. When he finally arrives in the Philippines, he meets a native priestess who leads him away from the singular god of Christian doctrine and toward the worship of multiple gods, as "[h]e had been trained to think of religion as urbanity but, watching the priestess worship, could not but feel how right it was that she should look as wanton and sinister as the rite itself, as the jungle itself". As lovers, the two joined forces to wage battle against the Spanish colonial governor and his army so that "[b]y mid-August the Archbishop and the Princess had advanced downriver and established their headquarters in the cave of the hill called Lakan Bato, almost within sight of the city" (221). Garnering support from other rebels in Manila, they created a formative resistive front against the governor's army. Separating from the archbishop to rally the rebels in other areas of the country, they parted ways and the archbishop was eventually attacked, seized, and killed at the hands of the governor. After being buried under the auspices of a royal Spanish funeral fit for religious authority with no mention of his denunciation and betrayal of the crown, his body was eventually exhumed because his grave attracted a flood of daily visitors devoted to the idea that he was not dead but only sleeping as he awaited the continuation of the struggle. In 1896, nearly two centuries after his supposed death, anti-colonial resistance leader Andres Bonifacio led peasant forces against the colonial regimes of Spain and the United States. Joaquin traces Bonifacio's outline against the archbishop's contours, for the "mountain folk. . .were sure of having seen in [Bonifacio] and his wife the insurgent pair of legend, prelate and priestess, who might seem to fall and die but had only vanished from sight and would be returning again when the time came" (226). Bonifacio and the archbishop follow a single strain of anti-colonial resistance, connected through the struggles against colonial power revealed in otherwise disparate histories. Where Bonifacio might be usurped as a leading figure of a revisionist, nationalist history of the plight of the Filipino, Joaquin's conceptualizations of Bonifacio here as another if not the very same iteration of Spanish-indio collaborative resistance conceives of Filipino national identity as not only emerging from the consolidation of racialized subjectivities under the specificities of Spanish authority in the Philippines but also under the violence of an unceasing colonial conquest.

Kritika Kultura 24 (2015): -092

(C) Ateneo de Manila University

<http://kritikakultura.ateneo.net> 
What might it reveal that Joaquin "resuscitates" such figures of the religious movements under the Spanish colonial regime of the $17^{\text {th }}$ and $18^{\text {th }}$ centuries in the Philippines in 1972 on the eve of Marcos's declaration of martial law; that La Hermana Beata settled in solitude in the cave where the archbishop and the priestess met and consummated a relationship committed to anti-colonial rebellion; that Andre Manzano fell victim to the typhoon at the edge of the same Lakan Bato? Nowhere are these questions made more explicit than in the interweaving inextricability of the characters La Hermana Beata of centuries past and Nenita Coogan of the 1970s, whose parallel and intersecting stories become Joaquin's way of mapping concerns about the nature of subjectivity under colonialism and the nationalist recuperations of identity under a distinctly authoritarian order on the same temporal and spatial plane. Insofar as Joaquin's concerns over religious authenticity embodied by the beatas of Joaquin's historical postulations and La Beata Hermana of his literary conjectures become methods of grappling with the complexity of Filipinoness as a medium of multiple modes of power, the emergence (perhaps, reemergence?) of Nenita in life and death destabilize Filipinoness in the 1970s as part and parcel of similar concerns about power and resistance. This is ultimately a quandary about the nature of official Philippine nationalism under decolonizing frameworks in the 1970 as grounded in colonial discourse. During the $17^{\text {th }}$ and $18^{\text {th }}$ centuries, Hermana inhabits a Philippines that has yet to conceive of Filipinoness as an overarching category of national belonging. In 1972, well into the post-independence period, the solidity of Philippine nationalism remains a largely unfettered concern. The difficulty with which Nenita finds place in the middle-class social circles where she lives and plays signifies Joaquin's insistence that national identity must continue to be questioned in the urgency of martial law and national development.

In the novel, the Barrio Bato is rediscovered in 1971, spearheading the explosive conflict between Christian and neo-pagan activists in Manila. At the novel's conclusion, Jack discovers that the mayor of the "suburban town" of Manila (and Jack's old friend), Pocholo Gaitman, is responsible for orchestrating the crime and mystery of Nenita's death. Pocholo explains to Jack:

Here were today's missionaries working to convert what Philippine tribes are still paganand where was the nationalist outcry against this corrupting of what remains of the true Filipino? Where the patriot protest against this cultural tampering with Filipinos who don't have to be de-colonized? I felt the nationalists weren't being consistent. Reviling the friars of the past for having converted us - wasn't that a futile exercise when the consistent thing to do would be to attack, to try to stop, the work of conversion still going on today, among us, among our pagans?

And here were these cults, in Pangasinan and the Mountain Provinces, that were trying to revive paganism in the Philippines. Was there a nationalist peep in defense of these neo-pagans? No, they were disdained as witch-doctors and hick miracle men. On the 
one hand Philippine paganism was being extolled as true Filipinism. On the other hand it was being scorned as mere superstition. (252)

Pocholo details the inconsistency of nationalist ideology in the Philippines, its concerted dismissal of colonial practice and simultaneous refusal to acknowledge its own enactment of similar practices in the name of nationalism. Pocholo's tirade comes as a response to Jack's discovery of his orchestration of the mystery, and it calls into question the nationalist and, perhaps, decolonial outcry for a return to a "true Filipino." In fact, "true Filipinism" also names a presidential address that Marcos gave to the Philippine Congress in which he lectured, at length, about his plans for the improvement of Philippine infrastructure, the reconstruction of the country's education system, the redevelopment of the national economy, and the recuperation of the morale of the Filipino spirit. Marcos's articulation of the Filipino's worth relies upon a regressive temporality that conceives of Filipinoness as having emerged from the wholeness of the native indio, an idea that was rooted in Marcos's conception that the indio can rightfully claim its position within any universal humanity. Pocholo's articulation of the Filipino, here, however, does not seek to recuperate it from history; instead, it details the methods by which the Filipino is made by history's progressive and developmental aims and disregard for the intricate and complex vyings for power and life that are often saturated within such overarching historical strains. This conception of the Filipino consequently contests Marcos's claims of true Filipinism as it reveals its complicity with the project of history guided by colonial modernity. The danger of any claim to true Filipinism, as Pocholo describes above, is that it denounces colonial practice in the name of national sovereignty even as it remains tethered to the methods of governance that wage war and violence upon those not fit for inclusion into the national community; or, as Pocholo explains to Jack: "Look, Christianity used the sword, the whip, the gun, the fraud and the lie to establish itself in this country and we're prepared to be just as ruthless in defeating it and reestablishing ourselves again in our own land" (258).

In the passage above, Pocholo describes the violence of Philippine nationalism in its invocation of the true Filipino, detailing the inconsistencies of claiming a "true Filipino" in the "undisturbed" communities of the Philippine tribes of the Pangasinan and Mountain provinces and yet continuing the work of converting these tribes to Christianity. Pocholo equates this nationalism with the work of religious conversion during the time of Spanish colonialism and the "friars of the past" (252). Here, Pocholo describes the true Filipino as the hotbed of these ongoing and simultaneous conflicts between the force of nationalism to denounce its colonial past and the work of national identity to impose another form of violence. Here, then, Pocholo articulates Filipino subjectivity as borne from such processes of continuous making and unmaking. In describing the ways that Christianity utilized the sword, the whip, the gun, the fraud, and the lie, he articulates violence 
as wielded just as much by the physical force of war and bodily suppression as the implementation of the force of ideology. Insofar as he traces this trajectory between the imposition of colonial violence under the religious order and the implementation of nationalist ideology, it is this articulation of Filipinoness that imposes modes of colonial violence in the nationalist fervor of the 1970s. True Filipinism as official state policy under Marcos thus names the formation of Filipino subjectivity as the crux of state violence.

\section{THE FALSITY OF TRUE FILIPINONESS}

To return to Chakrabarty's earlier assertion that the novel form functions to express the modern self, Joaquin's novel provides an apt albeit curious example. As the novel's protagonist and private detective, the unfolding of the mystery depends upon Jack's conceptualization and untangling of it. Put crudely, it is only through Jack's terms that the mystery can be conceived, for it is Jack's consciousness that defines the contours of its knowability. Yet, the solidity of Jack's subjectivity as the novel's principle investigator and the center through which the narrative unfolds lies in deliberate antagonism to the irresolution of the mystery of Nenita's death so that Jack's coherency as a Filipino subject must simultaneously grapple with these contestations to Filipino subjectivity. While the novel follows Jack as he attempts to solve the mystery of Nenita's death, the narrative does not result in a truer understanding of the problem but, instead, follows the disintegration of Filipinoness as a mode of identification. When Jack visits Ginoong Ina, the present-day leader of the neo-pagan movement in the Philippines, to seek answers about Nenita's death, she explains to him, "Mr. Henson, Nenita Coogan was a mixed-up kid because she didn't understand why people professed to be what they weren't and concealed what they really were. She went through the Christians, hippies, activists, and got no answer. Then she came to us and began to understand why" (Joaquin, Cave and Shadows 146). Here, Ginoong Ina describes the ways that Nenita's disjuncture within her social circles her incomprehensibility as a true Filipina because of her American national identity and her whiteness made her particularly adept at interrogating the nature of Filipino identity. In another instance, Chedeng explains to Jack the reason that Nenita's parents sent her away from the United States to live in the Philippines: "[T] hey realized that moving to a new place only gave Nenita a new world to explore and expose. That's when they decided to send her over here. I suppose they thought she couldn't, so to put it, uncover a native here where we are all natives. Were they ever wrong"' (57). Nenita's perplexing truth-seeking project which ultimately functions not to uncover any defining truth but to fabricate a set of unwieldy stories illustrates the falsity of any one single identity. Put simply, Nenita's 
friends and acquaintances are an array of multiple experiences. More interestingly, however, her fascination with uncovering the "native" and then coming to the strange realization that no native exists in the place where all people are presumed to be native points to the puzzling quandary of Filipinoness to adequately embody any singular subjectivity but, instead, to encompass a continuously shifting array of meaning-making processes. Emerging from a desire to belong within various Philippine social circles coupled with a simultaneous rejection from these social circles, Nenita's inquisitiveness about the prerequisites for belonging forms, in many ways, a critical apparatus with which to dismantle the coherency of Filipino identity in the novel.

According to Ginoong Ina, Nenita's death was not simply a death but a transference of spirit and power between the pagan goddess and Nenita, "[T]he goddess came into me as in the fullness of time she enters all her priestesses. Before, I had to go into a trance to make contact, but now the goddess dwells in me. So she entered that woman of the $17^{\text {th }}$ century whom they knew as La Hermana Beata. And so she entered Nenita Coogan in the hour of her death" (147). Here, the "loss" of Nenita in the present produces a connection between multiple historical trajectories in order "to undo four hundred years of history" (149). Ginoong Ina explains that "irreverence towards nature is fast making the country unlivable. The mountains are deforested, the soil languishes, river and sea stink, the very air is poisoned" (148-9). Turning to Jack, she chides, "Private conscientiousness like yours... will not save us. What's needed is the old heathen pieties made communal again" (147-8). In describing her own religious practice, Ginoong Ina aligns this irreverence toward nature with nationalism as a religion and thus explains that the developmental modes of Philippine national politics are making the country unlivable. Her call for a "communal" practice that "must return to the cults of the anitos," which lies in antithesis to Jack's "private conscientiousness," is a critical disinvestment in individualized subjectivity and its belief in the advancement of Filipino identity as a political instrument with which to address the life conditions of the country's people (149). For Ginoong Ina, the dismantling of historical time-the work of undoing four hundred years of history-reveals the violence of progress under modernized development. Insofar as historical time affords a kind of privacy to individualized, nationalist subjectivity, Ginoong Ina's rejection of this subjectivity creates a temporal and spatial framework that conceives of the ways that a nationalist investment in subject-making limits the extent to which the intricacies and intimacies of Philippine social life can be understood within a broader historical context. Insofar as Ginoong Ina explains to Jack that "[i]f we have to put on so many false faces it's because our basic face is itself false," she generates an alternative historical imaginary that both rejects the originary truth of nationalist subjectivity and also paves the way for a genealogical exploration of the ways that this subjectivity is molded and made as/through different regimes of conflict and power (146). Here, then, Jack's conversation with Ginoong Ina, rather 
than offer a more comprehensive illustration of who/what Nenita is/was and the mystery that shrouds her death, instead, leads to a series of questions aimed at deconstructing the solidity of Filipino subjectivity. The mystery of Nenita's death illustrates Joaquin's disinvestment in the coherency of Filipino nationalist subjectivity as a medium of decolonial politics and practice propagated through nationalist paradigms advanced not only by Marcos state policies but also by antistate resistance mandates.

Returning, again, to the importance of the novel form, each of Jack's attempts to make sense of the mystery of Nenita's death and of his own life is an iteration of his own weight and solidity as a fully realized subject. And with each of these discoveries is the revelation that there is no such thing as the recovery of any true Filipino. Herein lies a continuous interplay between claims for the coherency, cohesion, and wholeness of Filipino subjectivity and the persistent acts to undercut them. By novel's end, Andre Manzano has died from injuries he suffered during the catastrophic typhoon. His father, Alex, has committed suicide. The eldest Manzano, Don Andong, leaves the Manzano house to enter a monastery after losing both son and grandson. Chedeng flees to New York, Pocholo retreats underground after revealing to Jack his complicity in Nenita's mysterious death, and Monica refuses Jack after he attempts to persuade her to leave with him to Davao. Even as the legibility of Jack's character remains intact by the end of the novel, there is a certain disjuncture in the unfolding of historical time-the irresolution between the past symbolized by Jack's relationship to/with these characters and Jack's own present state-that complicates Jack's comprehensibility and validity as a fully developed protagonist and, more importantly, as a modern Filipino subject. Where these minor characters find themselves embodying only a residual presence by the end of the narrative, Jack is unable to recuperate his young self of the 1950 s with his current self in 1972 even though, as he explains to Monica, he badly "want[s] somebody from my world here in my new one down there" so that this nagging split must be given adequate narrative attention and place within the novel (270). Here, then, the logical conclusion typically afforded to the mystery novel is left in shambles, unable to cohere amidst the persistence of Filipino historical irreconcilability. As Jack finds himself struggling to recover all that he might have lost during this trip to Manila, to hold onto the markers and monuments that symbolize what he understands to be true, he desires in Monica a way to suture the disparate parts of his life: "Going, going, gone. As the taxi carried him down the driveway he felt himself being carried away from all the monuments of the past. But why should they be past and why should he be carried away if he chose not to be?" (271). As Jack weaves in and out of these existentialist thoughts, the final lines of the novel explain:

Señora Mónica sent her apologies but she could not see Señor Jack. She wished him a happy voyage and hoped they might meet again in the future.

Kritika Kultura 24 (2015): -092

(C) Ateneo de Manila University

<http://kritikakultura.ateneo.net> 
Alone to his taxi descended Jack Henson, leaving the great house called La Alejandría for the last time, resigned to a final departure from the past. Maybe being prized as a monument was not Monica's trip?

That night he flew back to Davao, a lonely man. (272)

Monica's persistent and demanding absence is an act of refusal against her potential absorption within Jack's narrative and his aggressive desire to achieve a more holistic sense of self in which the longing of his past might be reconciled with the loneliness of his present. Monica's resistance against being won as Jack's monument and also "seeing" and thereby acquiescing to his desires tears at the immobility of Filipino subjectivity advanced by Jack's protagonist sensibilities. The monument here refers to the old stone statues that adorn the periphery of the Manzano home previously longstanding but destroyed during the typhoon and Monica's refusal to be set in stone and inscribed within such progressive enactments of time. The fate of the monument thus illustrates a rejection of the totalizing aims of subjectmaking under the historical paradigms of colonial modernity and authoritarian myth-making. In this passage, Monica reconstructs time according to another temporality. In expending an affective labor of hope that she and Jack might one day meet again in the future Monica fashions an alternative time-space nexus that is not predetermined by Jack's own conceptualization of the past as it functions in accordance with the continuous making of his own self. This is a processual articulation of subjectivity that is not marked by the logics of colonial organization but, rather, paves the way for an altogether different type of life-making that rejects the developmental framework of modern time.

Joaquin's novel conceives of a Philippine historiography that centers Filipino subjectivity as the crux of the complex and intricate interweavings of colonial, imperial, national, and authoritarian power. To imagine Filipino subjectivity in this way as the telos of multiple strata of power and governance is to pay close attention to the ways that history bears its weight through the production of the modern self. This production is a project that masterfully spans the temporal and spatial confines of official wars, declarations, events, and heroes. Joaquin utilizes Michael Jackson's hit 1972 song "Ben" throughout the novel as a way to reveal the specificity and urgency of 1972. The song also creates a historical genealogy that attests to the magnitude of historical experience rather than submit to the limited promises of Filipino subjectivity within an otherwise universal history. When Jack interviews Bong, one of Nenita's peers, at the Café Rajah Soliman-a homage to the Muslim leader of the land of Maynila before Spanish conquest-he asks Bong about the song that currently plays at the café, the one that he heard when he first arrived to Manila: 
“Oh, that. Noise of the hour. Song called Ben. About a rat. Didn't you see the movie? All you hear now is that tune. When I hear it in the future I'll remember 1972."

At the boy's idle remark, Jack felt his body repeat its tremor in the cave. August, 1972. What if the griffin folk at the long table were costumed unknowingly for some future memory of a today to be looked back at as the eve of something? Today was, yes, an impending: it's the feeling I got when I arrived in the city and it comes with that tune. (38)

Bong describes, at once, the ubiquity of this "song of the hour" and its permanence as a definitive marker of the year 1972. It was this specificity that sent tremors throughout Jack's body. At Bong's explanation of the song, Jack marks the precision of August 1972 as an "impending," as something not yet known but whose urgency is undeniable. As a novel that looks retrospectively at the declaration of martial law, this impending points to the imperative historicity of martial law within the larger schema of Philippine history. That others might look back upon it "as the eve of something" underscores Joaquin's own exploration of the eve of martial law as provoking an interrogation of the authenticity of the Filipino as it converges with questions of nationalism and decolonization. As Jack describes here and as evidenced throughout the novel, "Ben" serves as the soundtrack to Jack's traversals throughout Manila. It also becomes the medium through which Jack transports to different temporal frames. Toward the novel's denouement, Jack hears the song again:

Listening to it, he heard another boy's voice lifted in song. His own? Alex's? Pocholo's? The sound in his hear was older than the hit tune it was hearing: boyhood itself was singing in pious innocence [...] But the boy in the jukebox was singing: 'Ben, the two of us will look no more... The other voice, the boy's voice from the past, faded away and Jack sat abruptly sobered, another boy speaking in his ear (260-1).

The song's pronouncements of boyhood manifest themselves through Jack's own thoughts of his youth with Alex and Pocholo so that it becomes unclear who is actually singing and whether the voice in Jack's head is that of the singer's, his own, or somebody else's altogether. Here, the song becomes enmeshed with Jack's memories so that each of the singular subjectivities of the singer, Jack, Alex, and Pocholo devolves into a collective entity. As the lyrics of the song explain, "I used to say 'I' and 'me' / Now it's 'us,' now it's 'we." Here, Joaquin facilitates the individual into a collective articulation of historical experience, illustrating a departure from the singular form of Filipino subjectivity toward an investment in the multiplicity of historical experience to adequately account for the complexity of Filipino lives under modernity. In other words, it is not only that the individualization of the 
"I" is made to feed the collective energies of the "we" but also that attention to the subject-making process makes possible an exploration of the intersecting modes of colonial and authoritarian power to structure the lives of people. As Jack leaves to return to the Manzano home for the last time, he demands to listen to the song another time. And "to the keening of the boy's voice he rode away on a taxi into a glare of sunrise that now and then darkened, as though something monstrous had passed. Jack had a moment's picture of the fallen angel whom the universe cannot contain moving with back bent under the sky, darkening it with his wings" (262). A biblical reference to the fallen angel of god that the "universe cannot contain," Joaquin's use of "Ben" generates an altogether otherworldly quality to Jack's experiences. The song allows Jack to envision if only for a moment a certain fall from grace. While this is reminiscent of a "Fall" that structures the ilustrado conceptualization of a break from the pre-history of Spanish colonialism and the commencement of a Philippine national history, there is something much more sinister about Joaquin's illustration of this rupture insofar as it pinpoints a kind of fissure from the realm of modernized subjectivity. More reminiscent of Benjamin's angel of history whose face is turned toward the debris of the past while its back is turned against progress even as it is being swept away by it this figure, as it moves with and through the song, conjures a darkening and a storm only before generating a new space with which to imagine Philippine historical experience.

As I have described, modern historical time is grounded upon a linear, developmental paradigm that traces the progression of humanity. Usurping this temporal framework, Marcos aimed to reconfigure Philippine history through a regressive temporality that sought to both prove the origins of Filipino humanity and also legitimize his rule as fated in history. I want to be clear here, however, that each of these conceptualizations of historical time unfolds along a similar temporal strain. In each iteration, whether it purports the humanistic origins of the Filipino or the evolution of universal man, it is liberal humanism grounded in the universality of the subject that guides the unfolding of historical time. What Joaquin's novel offers is a persistent interrogation of the Filipino subject not as original truth but as method of power. The concision of Joaquin's postulations about colonialism lies not in his articulation of its lasting effects on the Philippine sociopolitical landscape or the continuity of any colonial mentality but in the very decipherability of human life. In other words, Joaquin describes, in many ways, that the tenacity of colonialism lies in its power to define who/what counts as human and how life itself can be measured and organized. The authoritarian state under Marcos secured its power through the capitalization of this humanity for the progression of the Philippine republic on the global stage. The urgency with which Joaquin treats the period before martial law as "the eve of something," his 
notion of an impending, is generative for directing critical attention to an era that saw the geopolitical demarcations and reorderings spurned by the World War II victories of the Allied Powers. These manifestations of political power became the basis for a restructuring of the international arena in such a way that resulted in the economic systems that facilitated the growth of global capitalism on an unprecedented scale. It also reconceptualized the third world subject in ways that made this subject more sophisticatedly incorporated into these neoliberal systems of governance. For the Philippines, the insidious and lasting power of martial law lies not only in the evidence of the brute force Marcos used to suppress individual liberties but, perhaps contrastingly, in Marcos's work to aggressively nationalize Filipino subjectivity to conspire with the globalizing aims of a post-World War II global order.

\section{UNTANGLING MARCOS POLICY THROUGH JOAQUIN'S HISTORIOGRAPHY}

In using Joaquin's novel as theoretical guide, I consider briefly a specific example of Marcos's usurpation of Filipino subjectivity in order to advance specific state policies. In 1975, Marcos created the National Commission on the Role of Filipino Women (NCRFW) as an advisory board (with the First Lady, of course, as chairperson) for the President regarding all matters pertaining to the "integration of women as full and equal partners with men." The commission was responsible for conducting studies and lobbying for legislative measures that supported the equal treatment and advancement of women and for serving as an information center for all issues concerning women. More importantly, however, it was a direct product of the United Nations' declaration of 1975 as International Women's Year and 1976-1985 as the Decade for Women. The first World Conference on Women, held in 1975, moreover, drafted the Convention on the Elimination of All Forms of Discrimination against Women (CEDAW), which was eventually ratified in 1979. While the CEDAW intended to solidify a decree against the discrimination of women and to enact a formal agreement to advance all women around the world through their integration into all aspects of political, economic, and social life; it also served to construct an international norm around a particular definition of equality. This definition frames injustice only through the framework of subjectivity that women must be elevated to the status of men in order to facilitate global progress rather than through an interrogation of the very paradigm of liberal humanity that constructs and maintains such divides even as it purports to overlook them. The framework of equality conceives of the subject as a given rather than as always constituted and being made through the colonial and state power. In other words, framing political and social progress through the paradigm of rights gives people permission to participate in political, social, and civic life but fails to disrupt the very organizational order that emerges from capitalist and neoliberal systems of

Kritika Kultura 24 (2015): -092

(C) Ateneo de Manila University

<http://kritikakultura.ateneo.net> 
governance. The establishment of the NCRFW in the Philippines, in its alignment with UN goals, sought to bring the Philippines up to speed, so to speak, with modern global time. As scholars like Rhacel Parreñas, Robyn Rodriguez, Neferti Tadiar, and others have incisively argued, however, the integration of Filipinas into the global economy was, in fact, facilitated through the violent extraction of labor from women's bodies. The proliferation of multinational corporations around the globe, and particularly in the third world, not only mandated an increased demand for cheap labor but also necessitated the kind of physical dexterity that women's bodies were said to provide and which would ultimately ensure the efficiency of that production. Moreover, the strengthening of U.S. military presence in the Philippines through the continuation of its military bases fostered a sexual economy that did not simply demand women's sexual labor but institutionalized it as instrumental to the wellbeing of the national economy. While the establishment of International Women's Year and other similar practices of visibility and representation under the paradigm of equality sought to protect women through the political mandate of justice through rights, the continuous violence wrought upon women through the extraction of their labor was not merely intensified but made more sophisticated by framing women's subjectivity through the logics of equality.

Joaquin's genealogical reimagining of Philippine history is useful for considering these methods of subject-making under Marcos authoritarianism as interlocking with the colonial logics of conquest and production that made the Philippines integral to the proper functioning of the global capitalist economy in which the U.S. empire played a leading role. In other words, while Marcos's investment in the rights of women - that is, in the reconstitution of Filipina subjectivity through rights-based justice-is noteworthy and necessary on its own, divorcing it from the larger schema of globality and modernization especially under the United Nations' human rights regime is to fail to understand the force of subjectivity to advance the goals of the global at the expense of the lives of third world and decolonizing peoples. In Joaquin's novel, the persistence of the goddess and her various earthly manifestations interrogate subjectivity as a medium for the patriarchal aims of colonial governance. As Joaquin reimagines time and space and allows these various pagan deities and figures to disrupt the solidity of Jack's consciousness, he illustrates the ways that the coherency of subjectivity occludes the embodied violences enacted upon the lives of Filipinas. But more importantly, this contestation of subjectivity showcases the modes through which subjectivity itself became an all-encompassing category with which to organize a sophisticated system of labor extraction and production that would continue well beyond the end of Marcos's administration. 


\section{Works Cited}

Chakrabarty, Dipesh. "Postcoloniality and the Artifice of History: Who Speaks for 'Indian' Pasts?" Representations 37 (Winter 1992): 1-26. Print.

--. Provincializing Europe: Postcolonial Thought and Historical Difference. Princeton: Princeton UP, 200o. Print.

Constantino, Renato. The Making of a Filipino: A Story of Philippine Colonial Politics.

Quezon City, Manila: Malaya Books, 1969. Print.

Foucault, Michel. "Nietzsche, Genealogy, History." Language, Counter-Memory,

Practice: Selected Essays and Interviews. Ed. D. F. Bouchard. Ithaca: Cornell UP, 1977. Print. Hidalgo, Cristina Pantoja. "The Philippine Novel in English into the Twenty-first Century." World Literature Today 74:2 (200o): 333-336. Print.

Ileto, Reynaldo. "Outlines of a Nonlinear Emplotment of Philippine History." The

Politics of Culture in the Shadow of Capital. Eds. Lisa Lowe and David Lloyd. Durham:

Duke UP, 1997. 98-131. Print.

Joaquin, Nick. Cave and Shadows. Manila: National Bookstore, 1983. Print.

Joaquin, Nick. Culture and History: Occasional Notes on the Process of Philippine

Becoming. Manila: Solar Publication, 1988. Print.

Marcos, Ferdinand E. Tadhana: The History of the Filipino People. 4 vols. Manila: N.p., 1976. Print.

Roces, Mina. "Filipino Identity in Fiction, 1945-1972." Modern Asian Studies 28:2 (1994): 279-315. Print.

San Juan, E. Jr. "Encircle the Cities by the Countryside: The City in Philippine Writing." Journal of South Asian Literature 25:1 (Winter, Spring 1990): 198. Print.

Tadiar, Neferti X.M. "Filipinas 'Living in a Time of War." Pinay Power. Ed. Melinda L. de Jesus. New York: Routledge, 2005. Print.

--. Things Fall Away: Philippine Historical Experience and the Makings of Globalization. Durham: Duke UP, 2009. Print.

\section{Notes}


1. The Woman Who Had Two Navels was published in 1961 and Cave and Shadows in 1983.

2. It should be noted that Joaquin only accepted the award in exchange for the release of political prisoner and writer Jose "Pete" Lacaba. Neferti Tadiar explains, "When martial law was declared, [Lacaba] went underground. Imprisoned by Marcos in 1974 for his partisan journalism and subversive activities, he was pardoned when his former editor, Nick Joaquin, a renowned writer who was named National Artist by the regime, asked Marcos to release Lacaba in exchange for his acceptance of the award" (188). See Tadiar's Things Fall Away.

3. Marcos established the National Artist of the Philippines award by Proclamation 1001 in 1972. Such cultural development projects were fundamental to Marcos's establishment of his New Society.

4. See Dipesh Chakrabarty's Provincializing Europe.

5. Ileto's discussion, from his essay "Outlines of a Nonlinear Emplotment of Philippine History," draws from the historical textbooks of Teodoro Agoncillo, which traces Philippine history from a pre-colonial era to the emergence of Philippine nationalism during the U.S. colonial period. Ileto discusses the ways that this historiography unfolds along a series of binaries that trace the emergence of the Philippine nation-state out of darkness. Agoncillo's and Ileto's formulation of Philippine history draws heavily upon the pasyon narrative, which follow the story of Christ's redemption. Ileto discusses this at length in Pasyon and Revolution and other works.

6. I owe much of this reading of Joaquin's novel as a genealogy of martial law upon Foucault's theorizations of historiography. Insofar as the work of history is to narrate a past that can justify the present and portend a future, such a narrative depends upon the temporal logics of modern time and assumes both a proper place of return and the assurance of a future. For the postcolonial a misnomer inasmuch as the "post" refers not to a completed process but a different one what is the past if not always already the present? And how can the future not be constructed through terms already designated by colonial power? This compartmentalization of time portends a precolonial time to which the present has little access and points toward an overdetermined future, all of which obfuscate colonial systems of organization that remain in place well beyond the reach of modern temporal designations. The postcolonial is always already engaged in the act of becoming, a process for which history cannot always account. Not a counterhistory, then, but a reconceptualization of historical occurrence, a genealogy attempts to reveal the overlapping mechanisms of power and domination at work in the formation of such narratives. In "Nietzsche, Genealogy, History," Foucault offers a reading of Nietzsche's Genealogy of Morals that defines genealogy as that which refuses the origin, follows the path of descent, and maps an effective history onto the body. Foucault writes that a genealogy "does not oppose itself to history as the lofty and profound gaze of the philosopher might compare to the molelike perspective of the scholar; 
on the contrary it rejects the metahistorical deployment of ideal significations and indefinite teleologies. It opposes itself to the search for 'origins"' (140). A genealogy, as Foucault explains, is not a counterhistory; it does not reject attempts to record a narrative. It is, however, critical of the aims that history assumes in its ongoing quest for meaning, the result of an obsession with the "origin," which "makes possible a field of knowledge whose function is to recover it, but always in a false recognition due to the excesses of its own speech" (143). For Foucault, the presence of the origin promises a truth that can never stand on its own but is only made possible through the creation of a discourse. Moreover, the origin is a moment of divinity that locates man within the realm of the gods, in his most perfect state, and signals a sovereignty to which he must return. The origin "comes before the body, before the world and time" (143). Foucault responds to this critique of the origin with a call for examining the Herkunft or the descent. Rather than highlight the battles, victories, losses, and passage of specific "events," the descent follows "passing events in their proper dispersion" and identifies "the accidents, the minute deviations - or conversely, the complete reversals - the errors, the false appraisals, and the faulty calculations that gave birth to those things that continue to exist and have value for us; it is to discover that truth or being does not lie at the root of what we know and what we are, but the exteriority of accidents" (146). In contrast to the origin, which assumes a pre-established meaning before the enactment of that meaning, the path of descent urges that meaning is made in the accidents and errors of interaction, within the "hazardous play of dominations." These meanings are the Entstehung or emergences that are created in the interstices of these "confrontations." While history places emphasis on the placefulness of a significant occurrence or event, genealogy seeks the placelessness ["non-place"] of these accidents. Foucault argues that the body reveals an "effective history" enacted by genealogy, for the body "is molded by a great many distinct regimes; it is broken down by the rhythms of work, rest, and holidays; it is poisoned by food or values, through eating habits or moral laws; it constructs resistances." Power enacts meaning onto the body by transforming the body into the self. See Michel Foucault's "Nietzsche, Genealogy, History" in Language, CounterMemory, Practice.

7. Joaquin writes that by 1748 under Mother Ignacia, the beatas "were educating 45 girls - native, Spanish, and mestiza - and the number swelled the following year to 30 native girls, 20 Spanish girls, and four Negro women. . A pioneer labor of the beaterio was the conducting of retreats for women, retreats that drew native women from all over the city and neighboring towns as well as Spanish ladies and mestizas, sometimes as many as '200 Spanish women and from 50 to 80 mestizas.' All of these women of diverse races gathered as one, lived in community during the eight days of each retreat, and together performed the spiritual exercises within the beaterio, 'to the great benefit not only of themselves but of the communities they came from.' Racial integration started in the beaterios" (121). 
